\title{
Tradisi Bakaba dalam Rabab Pasisia: Sebuah Adaptasi Menjadi Film
}

\author{
Desmawardi, Hanefi, Maisaratun Najmi \\ Program Studi: Karawitan, Fakultas Seni Pertunjukan \\ Program Studi:Televisi dan Film, Fakultas Seni Rupa \\ Institut Seni Indonesia (ISI) Padangpanjang \\ Jln Bahder Johan Padangpanjang 27128 Sumatera Barat \\ Email: desmawardi.sutanmudo@gmail.com
}

\begin{abstract}
This paper is about kaba gadih basanai through music media of Pasisia rabab. Melodi movement accopanyiang the dendang. Whil the presence of the presenseof the rabab melodi stands alone, only in the introduction, interlude delivery or bridgeof on vokal melodei to the next melody. The dendang melody ia rabab,s speech melody that tell the Story. The method used in this research is a qualitative method, with a deskriptive analysis aproach. Literature study related to the musical aspects of the persentation of the musikal traditional of the rabab pasisia kaba gadih basanai. The source of the melodies comes from the song Sikambang tinggi and Sikambang data. The two melodic sources epress certain parts of the story in kaba, the musical expression determines the content of the story being told. Pasisia rabab musical expression reveals the life journys of basanai such as sadness, joy, conflicts, and solutions. The expressive picture musiclly becomes a conceptual coplentenness of the adaptation of kaba which is conveyed by the media of rabab pasisia music towards film gadih basanai
\end{abstract}

Keywords: Bakaba Tradition, Adaptation, Film

\begin{abstract}
ABSTRAK
Tulisan ini berisi tentang kaba Gadih Basanai melalui media musik Rabab Pasisia. Pergerakan melodi rabab mengiringi dendang, dan kadang kala juga berjalan sendiri seperti saat introduksi, interlude. Melodi dendang adalah melodi tuturan tukang rabab dalam menyampaikan cerita. Metode yang digunakan dalam penelitian ini adalah metode kualitatif dengan pendekatan deskriptif analisis. Studi Pustaka yang berhubungan dengan aspek musikologis penyajian tradisi musik rabab pasisia kaba Gadih Basanai. Sumber melodis berasal dari lagu Sikambang tinggi dan Sikambang data. Kedua sumber melodis itu mengekspresikan bagian-bagian cerita tertentu dalam kaba. Ekspresi musikal rabab pasisia mengungkapkan perjalanan hidup Gadih Basanai seperti kesedihan, gembira, konflik, dan penyelesaian. Gambaran ekspresif secara musikal menjadi kelengkapan konseptual terhadap adaptasi kaba yang disampaikan dengan media musik rabab pasisia menuju film Gadih Basanai.
\end{abstract}

Kata Kunci: Tradisi, Bakaba, Adaptasi, Film

\section{PENDAHULUAN}

Trend adapatasi novel dalam produksi film Indonesia direspon kritis oleh Deny Tri Ardianto. Pada tulisannya yang berjudul Dari Novel Ke Film: Kajian Teori Adaptasi
Sebagai Pendekatan Dalam Penciptaan Film.

"Pilihan adaptasi dalam produksi film secara prinsipnya didasarkan pada beberapa hal, salah satunya adalah popularitas novel yang dirujuk. Popularitas karya rujukan jadi 
semacam garansi terhadap jumlah penonton film yang akan diproduksi berdasarkan karya tersebut, Ardianto (2014: 19)".

Begitu juga hal nya dengan kaba Gadih Basanai yang terdapat di Pesisir Selatan Sumatera Barat, termasuk salah satu kaba yang populer dikalangan masyarakat pendukungnya. Istilah kaba dalam tradisi musik di Minangkabau diartikan dengan 'cerita lisan' yang diwariskan secara turun temurun secara lisan (oral tradition) dari satu generasi ke generasi selanjutnya. Penyampaian kaba atau cerita ini di tengah kehidupan masyarakat Minangkabau pada umumnya mengandung unsur-unsur seni, misalnya seni sastra, seni musik, seni teater, dan seni tari. Unsur-unsur seni sastra dapat dilihat dari bentuk kaba itu sendiri, berupa syair, gurindam, pantun, bidal, dan seloka. Unsur musik dapat dilihat dari gerak melodi yang dihasilkan, yang diiringi oleh alat musik tertentu sesuai dengan konsep musikal yang dipahami seniman bersangkutan. Unsur teater dapat dilihat dari isi dan karakter yang dilahirkan oleh kaba melalui peristiwa tokoh dalam cerita.

Ada beberapa jenis kaba yang berkembang di Minangkabau, alat musik pengiringnya juga berbeda. Salah satu jenis kaba yang tumbuh dan berkembang hingga kini di daerah Kabupaten Pesisir Selatan adalah kaba "Gadih Basanai" yang diiringi dengan alat musik rabab pasisia. Istilah rabab pasisia merupakan istilah yang datangnya kemudian yaitu ketika musik tradisional ini berkembang ke musik komersial (industri rekaman), sebelumnya disebut secara tradisional dengan istilah biola atau babiola oleh masyarakat pendukung dan pemiliknya yaitu masyarakat Kabupaten Pesisir Selatan (Darmansyah, 2013 hlm. 64).
"Alat musik rabab pasisia terdiri dari dua bagian: 1) bagian batang rabab dan 2) bagian badan (resonator) rabab. Bangunan alat musik rabab pasisia ini mirip dengan bangunan alat musik biola atau violin (Barat) termasuk ke dalam klasifikasi organologis yaitu keluarga chordophones kelompok bowed lute, jenis violin (Hajizar, 1995, hlm.122.)"

Pada bagian lain Hajizar juga pernah menuliskan perkembangan wilayah pencinta rabab pasisia.

Budaya musik rabab pasisia tumbuh dan berkembang di Kabupaten Pesisir Selatan, wilayah kebudayaannya meliputi wilayah sepanjang pantai pesisir selatan Minangkabau yang meliputi lingkungan nagari Siguntua Tuo, Siguntua Mudo, Baruang-baruang Balantai, Tarusan, Pasa Baru, Talaok, Koto Marapak, Asam Kumbang, Gurun Panjang, Lumpo, Salido, Painan, Batang Kapeh, Surantiah, Ampiang Parak, Kambang, Lakitan, Labuan, Balai Salasa, Sungai Tunu, Punggasan, Aia Haji, Indopuro, Tapan (berbatas dengan daerah Kerinci), Lunang, Silauik (berbatas dengan daerah Bengkulu) (Hajizar, 2013, hlm.117-118).

Repertoar yang penting dan merupakan dasar dari kehidupan musik tradisional rabab pasisia adalah lagu Ratok Sikambang. Lagu Ratok Sikambang yang diyakini tertua di daerah budaya pasisia (Pesisir Selatan) adalah sumber (inspirasi) para senimannya dalam perkembangan selanjutnya yang kemudian melahirkan sejumlah lagu seperti: Lagu Sikambang Aia Aji, Sikambang Gadih Basanai, Sikambang Lagan, dan Sikambang Aia Tajun.

Lagu Ratok Sikambang sebagai musik vokal tradisional berfungsi sebagai pembangun spirit sosial oleh masyarakat di daerah Batang Kapas yang bersumber dari fenomena topikal di dalam tema teks kaba (cerita) yang disajikan tukang biola [tukang rabab]. Inti fenomena ini terletak pada kegamangan seseorang 
dalam menghadapi kehidupan yang semakin keras dan menantang, baik hidup di kampung halaman, maupun kehidupan di perantauan. Penikmatan terhadap penyajian lagu Ratok Sikambang telah fungsional bagi masyarakat pendukungnya untuk memunculkan tekad perjuangan hidup mereka di masa depan yang lebih baik. (Darmansyah, 2013, hlm.120-121).

Di antara sejumlah lagu hasil perkembangan secara tradisional dari Ratok Sikambang disebut juga oleh masyarakatnya "Basikambang" adalah lagu kaba Sikambang Gadih Basanai. Lagu kaba ini disukai dan populer hingga kini di tengah kehidupan masyarakat pendukung rabab pasisia. Lagu kaba ini disebut oleh masyarakatnya dengan sebutan Sikambang Gadih Rang Basanai atau kaba Gadih Basanai.

Garapan teks dalam bentuk prosa lirik yang diperkuat dengan teks berbentuk pantun bersajak berisikan susunan kata pernyataan-pernyataan, perumpamaan atau analogi-analogi kiasan sebagai penguat alur cerita yang sedang jalan. Selain itu, kehadiran teks yang memberi "kedalaman" ekspresi berupa silabel kata tambahan bertujuan untuk memberi "tekanan" tertentu terhadap isiteks yang dituturkan.

Sejauh observasi yang dilakukan, ternyata gagasan ini sangat didukung oleh pihak-pihak yang terkait dengan seni budaya seperti aparatur pemerintahan dalam hal ini Kepala Bidang Kebudayaan Kabupaten Pesisir Selatan, tokoh budayawan, seniman setempat, serta beberapa orang tokoh-tokoh adat.

Penelitian rabab pasisia dilakukan untuk mengetahui sebuah warisan tradisi lisan (oral tradtions) berupa cerita rakyat yang dikenal dan dipelihara oleh masyarakat pendukugnya yaitu masyarakat Kabupaten Pesisir Selatan Minangkabau hingga kini. Cerita rakyat tersebut dituturkan kepada masyarakatnya melaluimedia musik tradisional, lebih tepatnya kaba Gadih Basanai yang lahir bersamaan dengan kehadiran musik tradisional rabab pasisia di tengah kehidupan masyarakatnya. Musik tradisional merupakan salah satu cabang seni yang mengandung unsur-unsur estetis, unsur-unsur itu adalah:

“-wujud (appearance) seni (musik), yaitu wujud bunyi yang dapat diteliti dan di analisis komponen-komponen susunannya. Terdiri dari dua konsep, bentuk (form) dan susunan atau struktur.

-Bobot atau isi (content, substance), yaitu isi atau bobot peristiwa kesenian meliputi dilihat, dirasakan atau dihayati sebagai makna dari wujud kesenian itu, mempunyai tiga aspek: suasana (mood), gagasan (idea), ibarat atau pesan (message).

-Penampilan atau penyajian (presentation), yaitu mengacu pada pengertian bagaimana kesenian itu disajikan kepada penikmatnya. Untuk itu ada tiga unsur yang beperan: bakat (talent), keterampilan (skill), sarana atau media" (Djelantik, 2008, hlm. 17-18).

Musik tradisional rabab pasisia sebagai media estetis yang mengandung unsur-unsur wujud, bobot, dan penyajian sebagimana yang dikemukakan di atas, lalu membawakan suatu kaba (cerita rakyat), maka peristiwa penyajiannya kepada masyarakat pendukung tradisi musik tersebut akan mengandung makna yang berbeda apabila kaba tersebut dituturkan tanpa media musik. Unsurunsur estetis dari peristiwa-peristiwa isi kaba itulah yang akan diungkap dalam penelitian ini agar dapat lebih lengkap dan berdasar mengadaptasinya menjadi sebuah film. 


\section{METODE}

Metode penelitian merupakan rancangan langkah-langkah kerja yang dipersiapkan oleh peneliti untuk melaksanakan proses penelitian guna menjawab (rumusan) masalah penelitian dalam rangka mencapai tujuan penelitian. Langkah-langkah kerja tersebut disusun dengan berpedoman pada ilmu, pengetahuan, maupun pengalaman peneliti. Masalah penelitian merupakan suatu yang sangat menentukan metode penelitian. Masalah penelitian akan menentukan jenis penelitian yang akan dilaksanakan, data dan sumber data, teknik pengumpulan dan analisa data, serta cara pengambilan kesimpulan penelitian.

Berdasarkan identifikasi data-data yang dibutuhkan serta identifikasi sumber data, maka ditentukan metode pengumpulan data. Adapun metode yang akan digunakan dalam penelitian ini meliputi :1) pencatatan teks kaba Gadih Basanai; 2) Observasi penampilan kaba dan kultur masyarakat ; 3) Wawancara dengan penutur kaba dan masyarakat;4) Studi Pustaka mengenai tulisan maupun format lain yang berhubungan dengan kaba Gadih Basanai.

Sebagaimana yang ditawarkan dalam judul penelitian ini yakni berbicara tentang adaptasi dari seni pertunjukan tradisi rabab pasisia menjadi film, tentu akan memerlukan berbagai metode dengan pendekatan dan langkah sebagi berikut:

\section{Penentuan Sampel}

Setelah diadakan penelitian ke lapangan ternyata kaba Gadih Basanai dalam tradisi musik rabab pasisia ini terdiri banyak versi, dari sekian banyak versi itu kami memilih versi Idris, karena menurut masyarakat setempat penyampaian kaba Idris ini masih kental tradisinya dibanding yang lain. Berdasarkan pendapat tersebut pada tahun pertama ini kami jadikan skenario film Gadih Basanai yang akhirnya nanti menjadi sebuah film.

\section{Penentuan responden dan lokasi penelitian}

Demi terwujudnya responden sebagai sampel dan lokasi penelitian disesuaikan dengan permasalahan yang diangkat antara lain;

a. Generasi muda, meliputi masyarakat penggemar tradisi musik rabab pasisia yang berada dibeberapa kecamatan.

b. Beberapa grup musik rabab pasisia yang berada di Kabupaten Pesisir Selatan

c. Lembaga kesenian yang ada di Propinsi Sumatera Barat.

d. Tokoh-tokoh masyarakat yang berada di wilayah Pesisir Selatan yang dianggap mengerti tentang kaba dalam pertunjukan rabab pasisia, serta adat istiadat Minangkabau.

\section{Sumber Data}

\section{a.Data Primer}

Data primer diambil dari hasil observasi di lapangan yang berhubungan dengan permasalahan kesenian (musik) rabab pasisia, baik mengenai sejarah dan perkembangannya.

\section{b.Data Sekunder}

Data sekunder adalah data-data pendukung yang berasal dari bukubuku serta dokumen-dokumen yang ada kaitannya dengan permasalahan.

\section{Pengumpulan Data}

Adapun metode kualitatif yang dipakai 
untuk mengumpulkan data adalah:
a.Kepustakaan
b.Partisipan Observasi
c.Wawancara

\section{Analisis Data}

Langkah selanjutnya adalah menganalisis data yang telah terkumpul dengan memilih yang mempunyai kaitan dengan permasalahan yang sedang diteliti. Selanjutnya dilakukan pengolahan data dengan metode deskriftif analitik, yaitu mengolah data dengan cara menuliskan data data yang diperoleh di lapangan, sehingga dapat dilihat realisasi dari masalah yang diteliti dan sesuai tidaknya dengan pelaksanaan yang ada. Setelah semuanya terselesaikan barulah dilihat yang dianggap bagus dan mewakili kaba Gadih Basanai untuk sebuah film.

\section{HASIL DAN PEMBAHASAN}

\section{Ekpresi Penutur Kaba Rabab Pasisia}

Berbicara mengenai ruang ekpresi penutur kaba tentu tak terlepas dari kedalaman pemahamannya terhadap kaba yang dituturkan. Kedalaman pemahaman itu akan menentukan lahirnya rasa musikal yang berbeda bagi setiap penutur (tukang kaba). Musikalitas rabab pasisia tidak terlepas darikearifan estetika tradisional seniman yang mewariskannya.

Seniman sangat peka dengan relasi alur cerita dengan ruang dan waktu (setting) sebagaimana yang ia tuturkan, urut-urutan peristiwa yang terkait dengan tematiknya menghadirkan ruang dan waktu penceritaan. Waktu penceritaan sebagai waktu 'penanda' dan waktu penceritaan sebagai waktu 'petanda'
(Monaco, 2000) Waktu penceritaan dapat berkaitan dengan dua pemahaman: pertama, waktu sebagai durasi yaitu yang digunakan untuk menceritakan peristiwa; kedua, waktu yang digunakan sebagai latar waktu (Puspitasari, 2016, hlm. 367).

Secara tradisional, tukang rabab menempatkan latar waktu cerita bervariasi, waktu sebelum kolonial dan waktu pada masa kolonial di daerah setempat; waktu sebagai durasi penuturan tukang rabab, dapat berdurasi satu malam pertunjukan dan bisa pula bersambung ke malam pertunjukan berikutnya (dua malam pertunjukan).

Secara musikal, unsur-unsur musik tradisional yang dimainkan oleh semua seniman pada dasarnya sama, namun karena seniman adalah manusia biasa yang memiliki kapasitas talenta musikalitas dan pengalaman yang berbeda-beda tentu memiliki pula ciri khas masing-masingnya. Perbedaan karakter individu dalam mengekspresikan rasa musikal rabab pasisia terbentuk oleh pengalaman kehidupan tradisi kesenimanannya. Peristiwa ini akan melahirkan atau mempengaruhi pergerakan tubuh sebagai media ungkap dalam melahirkan bahasa yang disampaikan oleh penutur yang lahir atas kehendak diri sendiri. "Sebagaimana konsep disiplin tubuh menginginkan suatu yang otonom dari kehadiran bhasa sebagai media ungkap manusia. (Andi Taslim, 2019, hlm. 105)"

Kaba Gadih Basanai, dalam repertoar tradisi musik rabab pasisia disebut Sikambang Gadih Basanai maka kata "Sikambang" menunjukkan nyanyian sedih (ratok). Sebagai nyanyianyang sedih tentu melodi-melodi rabab harus mengesankan rasa sedih dalam konteks 
budaya masyarakat setempat sebagaimana yang mereka (para seniman) warisi. Di sinilah letaknya masing-masing seniman menafsirkan kesedihan itu sangat terkait dengan bakat dan pengalaman hidupnya berkesenian di tengah masyarakat, lalu diekspresikan secara musikal kepada masyarakat pendukungnya.

\section{Aspek Musikal Rabab Pasisia}

"Rabab merupakan salah satu alat musik tradisional Minangkabau jenis musik gesek yang digunakan untuk mengiringi dendang dan kaba (cerita rakyat Minangkabau) (Elina, 2018, hlm. 308)". Secara musikal, unsurunsur musik tradisional yang dimainkan oleh semua seniman musik tradisional rabab pasisia pada dasarnya sama, namun karena seniman adalah manusia biasa yang memiliki kapasitas talenta musikalitas dan pengalaman yang berbeda tentu memiliki ciri khas masingmasing. Perbedaan karakter individu dalam mengekspresikan rasa musikal rabab pasisia akan melahirkan perbedaanyang mencirikan individu seniman dengan latar belakang pengalaman kehidupan senimannya. Biasanya ciri-ciri itu cendrung pada estetika musikal seperti variasi-variasi dan ornamentasi melodis, namun dalam pelahiran musiknya tetap berada dalam frame prinsip-prinsip cengkok tradisional yang pada umumnya dipahami oleh setiap seniman rabab pasisia.

Membicarakan aspek musikal yang pada dasarnya mengandung struktur musik pula dalam sajian kaba dan struktur yang sama pada umumnya digunakan pula untuk repertoar Ratok Sikambang yang lain. Berbagai macam kesedihan dalam kaba diinterpretasikan oleh tukang rabab (pemain rabab) kemudian dilahirkan berupa melodi-melodi nyanyian diiringi oleh melodi-melodi rabab. Sepanjang alur cerita, muncul bermacam-macam suasana yang membutuhkan dukungan melodi rabab, yang sangat menarik adalah kemampuan seorang seniman yang membawakannya, di samping ia menyanyikan cerita ia juga memainkan melodi rabab; keadaan seperti itu akan membuka 'ruang imajinasi jiwa tukang $r a b a b^{\prime}$ mengekspresikan unsur-unsur musikal mengungkap "kedalaman" cerita. Kita akan sependapat bahwa segala sesuatu yang diungkapkan (diekspresikan) berasal dari diri seniman itu sendiri. Dia tidak dibantu oleh orang lain seperti halnya satu orang memainkan alat musik dan satu orang lainnya sebagai tukang dendang (penyanyi) sekaligus membawakan cerita-tentu ekspresi cerita menjadi penuh dan 'utuh' disajikan sesuai konsep yang ada pada "alam" dalam dirinya. Misalnya, tukang rabab hanya memainkan melodi-melodi rabab, sedangkan pandendang bukan dirinya maka belum tentu akan sesuai rasa atau penjiwaan yang lahir dari melodi rabab akan serupa dengan penjiwaan tukang dendang, begitu pula sebaliknya. Rasionallah bila penjiwaan nyanyian kaba dalam 'pangkuan' melodi rabab akan melahirkan rasa atau penjiwaan yang utuh bilamana kedua unsur tersebut dimainkan oleh seorang seniman.

Sebuah kaba dalam penyajian rabab pasisia mengandung struktur yang jelas secara tradisional terutama struktur keterkaitan tuturan melodis kaba dengan melodi alat musik rabab, jika diidentifikasi struktur 
dimaksud maka terdapat kesatuan-kesatuan terkecil yang saling terkait secara fungsional hingga menjadi satu kesatuan yang utuh secara keseluruhan. Kesatuan-kesatuan itu adalah wujud musikal rabab yang hadir "memangku" bagian-bagian dari alur cerita yang berfungsi membangun imajinasi "jiwa" cerita sesuai latarbelakang budaya Pesisir Selatan.

Menganalisis struktur musikal rabab pasisia kaba Gadih Basanai dilakukan pentranskripsian musiknya, dalam hal ini adalah melodi-melodi yang dibawakan alat musik rabab dan melodi-melodi vokal (dendang) yang dibawakan oleh penutur kaba. Dalam hal ini, transkripsi hanya mengacu pada kehadiran melodi-melodi rabab tanpa dendang dan melodi-melodi dendang yang dibawakan oleh tukang rabab itu sendiri. Sedangkan pentranskripsian digunakan sifat transkripsi preskriptif sebagaimana tawaran pentranskripsian musik etnik oleh Bruno Nettl sebagai berikut:

Pendeskripsian suatu komposisi musik merupakan suatu dasar (yang tidak bisa diabaikan) namun demikian, pendeksripsian tersebut sangat kurang berguna kalau dibandingkan pendeskripsian suatu kelompok komposisi-komposisi musik. Pembacapembaca buku etnomusikologi yang berpengalaman (kalau diberikan transkripsi komposisi tersebut) biasanya dapat membuat sendiri dalam waktu sekilas mata (atau paling lama beberapa menit) analisa-analisa seperti contohcontoh di atas (tidak dikutip dalam terjemahan ini --- M.P) Oleh karena itu, mendesk"ripsikan sebuah komposisi musik tidak begitu membantu pembacapembaca yang berpengalaman; malah pendeskripsi sendiri yang lebih beruntung transkripsi preskriptif (Nettl, 1964. Chapter 5: "Description of Musical Compositions"hlm. 99).

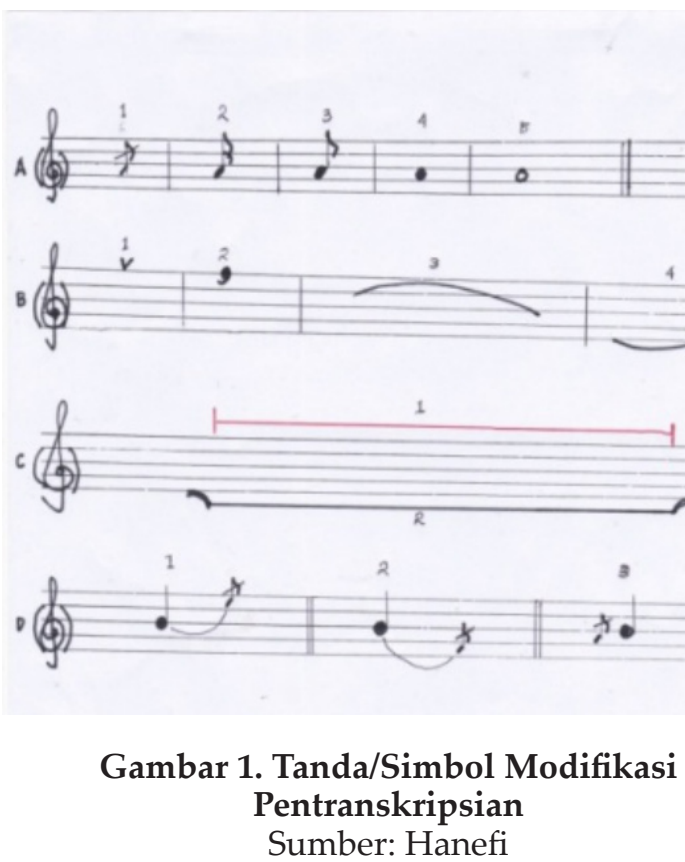

Pentranskripsian menggunakan transkripsi musik Barat (teori musik), namun objek yang ditranskripsikan adalah musik etnik maka dalam hal ini diperlukan modifikasi tanda-tanda dan simbol musik Barat tersebut. Adapun tanda-tanda atau simbol-simbol dimaksud adalah garis para nada dan tanda 'kunci' di tepi sebelah kanannya, tanda-tanda yang dibutuhkan sebagai batas kesatuankesatuan melodis, tanda atau simbol not-not yang efektif dan dianggap membantu proses analisis, dan lain-lain.

seperti pada gambar 1 yang mempresentasikan contoh modifikasi tandatanda atau simbol-simbol musik.

Pada gambar 1 di atas tanda kunci G di garis paranada disertai dengan tanda kurung (contoh: kunci G dalam garis merah) yang dimaksud adalah tanda modifikasi tandatanda di dalam paranada, bahwa semua tanda-tanda yang tertera pada garis paranada merupakan tanda-tanda atau simbol-simbol tidak terikat oleh teori musik Barat, namun 
tetap menggunakan kaidah-kaidah teori musik tersebut sejauh diperlukan. Pada huruf A nomor 1 (A1), sebagaimana teori musik Barat merupakan not/nada hias pada melodi, disebut appogiatura, namun dalam tulisan ini tanda tersebut selain not/nada hias juga digunakan untuk nada sangat pendek (lebihkurang 0,10 s/d 0,20 perdetik). A2, persis sama dengan not seperenambelas, dalam tulisan ini tidak ada pedoman metronom (MM) tetapi kehadirannya diperkirakan $\quad 0,40$ s/d $\quad 0,60$ perdetik. A3, sama dengan not seperdelapan diperkirakan di atas 0,60 s/d 0,90 perdetik. A4, sama dengan not seperempat diperkirakan 1 s/d 1,50 perdetik. A4, sama dengan not penuh diperkirakan di atas 1,50 s/d 2,50 persetik.

Pada huruf B nomor 1 (B1), adalah tanda batas satu frase melodis. Tanda ini khusus dipergunakan untuk melodi dendang. B2, tanda koma merupakan batas kehadiran melodi alat musik rabab tanpa melodi dendang. B3 dan B4, tanda hubung (legato dan ligatura) baik satu not ke satu not berikutnya dan dari satu not ke beberapa not lainnya sesudah itu.

Pada huruf C nomor 1 (C1) dan C2 berupa garis berwarna merah dibuka dan ditutup dengan garis pendek serta garis tebal warna hitam dibuka dan ditutup dengan garis melengkung. C1 merupakan tanda kesatuan frase melodi dendang sedangkan C2 sebagai satu kesatuan melodi rabab tanpa melodi dendang.

Pada huruf D nomor 1 (D1), D2, dan D3, adalah sifat pemakaian not appogiatura baik sebelum not di depannya maupun sesudah not di belakangnya. D1 tanda nada silabel teks yang dinyanyikan tukang rabab dengan tujuan memberi aksen dengan suara falsetto (Arab: Tasdik). D2 merupakan tanda memperpanjang nada silabel yang dinyanyikan mendapat tekanan singkat pada nada yang lain. Sedangkan D3 merupakan tekanan bahwa nada silabel teks yang akan didendangkan didahului dengan nada hias pada nada di tingkat bawah nada sebelumnya.

Modifikasi pentranskripsian tandatanda dan simbol-simbol pada gambar 1 memang harus dimengerti sebelum melihat notasi lagu, itu merupakan langkah-langkah membaca notasi musik etnik dengan sifat khusus musiknya. Mentranskripsikan musik rabab pasisia yang secara ritmikal bersifat ritme bebas (free rhythm) dan bagian-bagian tertentu dianggap berbentuk parlando rubato atau resitatif. Bentuk melodi bagian-bagian terentu itu seperti tuturan berbicara atau deklamasi disampaikan oleh tukang rabab. Sifat melodi yang free rhythm itu sulit ditemukan pulsa ritmisnya, lebih dari itu tidak bisa dihitung siklusnya membentuk suatu pola ritmik dalam melodi.

\section{Modus / Tangga Nada}

Dalam pentranskripsan musik kaba Gadih Basanai dituliskan pada satu kesatuan garis paranada, di awal setiap kesatuan garis paranada ditulis kunci $G$ dalam dua tanda kurung. Permainan melodi rabab yang sesungguhnya satu oktaf di atas nada-nada dendang (nyanyian), untuk memudahkan melihat proses analisis maka posisi nadanada melodi rabab diletakkan sama dengan posisi nada-nada melodi dendang dalam garis 
paranada yang sama. Nada terendah melodi pokok dendang berada pada nada $\mathrm{D} 4$ dan nada pokok tertinggi melodi dendang berada pada nada D5. Posisi yang sama diikuti pula oleh nada-nada melodi rabab.

Sebagaimana data yang diperoleh dari pernyataan tukang kaba Idris Kambang dan disetujui oleh seniman rabab pasisia Darmansyah bahwa dalam penyajian rabab pasisia kaba Gadih Basanai mengandung dua lagu repertoar tradisi sikambang, yaitu lagu "Sikambang Tinggi" dan lagu "Sikambang Data". Pada prinsipnya gerak melodi dendang lagu Sikambang Tinggi melangkah dan melompat disekitar nada-nada G4 ke nada D5, karena itu yang mencirikan lagu Sikambang Tinggi yang cukup spesifik adalah pola-pola kadensanya. Begitu juga gerak melodi melangkah dan melompat lagu Sikambang Data, bermain di sekitar nada-nada pokok dan nada G4 hingga turun ke nada paling rendah D4.

Ciri melodi lagu Sikambang Tinggi yang disatukan dengan ciri melodi lagu Sikambang Data dalam musik kaba Gadih Basanai dalam hal ini menghasilkan suatu modus. Modus (tangga nada) melodi lagu kaba Gadih Basanai dapat di paparkan sebagai di bawah ini.

Nada-nada pada modus (tangga nada yang digunakan) dalam kaba Gadih Basanai di atas adalah nada aktual yang dimainkan oleh tukang rabab pasisia bernama Idris Kambang (60 tahun). Interval modus itu memiliki dua interval $\mathbf{2 m}$ (sekon minor) dan lima interval 2M (sekon mayor). Secara berurut interval dimaksud yaitu: $2 \mathbf{M}-2 \mathbf{M}-2 \mathrm{~m}-2 \mathrm{M}-2 \mathrm{M}-2 \mathrm{~m}$ - 2M. Posisi interval dalam modus ini cukup menarik karena dalam lagunya terkandung

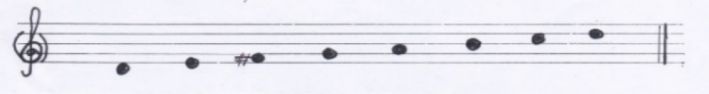

D4, E4, Fis4, G4, A4, B4, C5, D5

Gambar 2. Modus Melodi Kaba Gadih Basanai Sumber: Hanefi

pula dua lagu dar repertoar "Sikambang" yaitu Sikambang Tinggi dan Sikambang Data. Dalam hal ini dipahami bagaimana ciri melodi yang menggunakan masing-masing repertoar Sikambang. Dalam analisis berikutnya sangat perlu ciri-ciri itu diungkap karena melodi bersangkutan terkait langsung dengan ekspresi isi kaba.

Pusat nada biasanya ditentukan dalam suatu modus yang digunakan untuk sebuah lagu, artinya wilayah nada itu hanya untuk suatu modus tertentu. Khusus lagu kaba Gadih Basanai akan dilihat bagaimana posisi nada-nada akhir frase-frase melodis atau dapat dilihat sebagai pola-pola kadensa setiap kesatuan-kesatuan melodi (frase) yang akan menunjukkan posisi dominan untuk menentukan sumber melodi lagu mana dari dua repertoar "Sikambang" yang digunakan tukang rabab. Dilihat modus tertera di atas akan ditemui dominasi muara nada-nada dari lagu Sikambang Tinggi pada transkrip kaba Gadih Basanai, di samping itu lagu Sikambang Data telah menempati wilayah nada-nada rendah. Kesan-kesan demikian menunjukkan bahwa wilayah nada lagu kaba Gadih Basanai memiliki dua kesatuan wilayah nada yaitu wilayah nada-nada lagu Sikambang Tinggi dan wilayah nada-nada lagu Sikambang Data.

Istilah kesatuan melodi lagu kaba Gadih Basanai seperti istilah kesatuan melodi yang 
disebut motif melodis dan frase melodis, bagi kesatuan melodi alat musik rabab tanpa dendang disebut "motif" melodis jika kesatuan melodinya pendek, sedangkan "frase" melodis jika kesatuan melodinya relatif panjang. Batasbatas kesatuan melodi dimaksud memiliki kadensa dengan durasi nada akhirnya relatif panjang. Istilah motif dan frase melodis ini khusus hanya digunakan untuk analisis musik kaba Gadih Basanai.

Dalam tulisan ini, motif melodis tidak diberi identifikasi pada notasi yang di sajikan tetapi untuk kebutuhan menganalisis kaitannya denagan cerita maka ditampilkan frase melodis saja karena lebih mendukung untuk menafsirkan cerita terkait dengan melodi lagu sebagaimana garis-garis batas frase melodis terkait dengan frase kalimat.

\section{Aspek Musikal Kaba Gadih Basanai}

Pada uraian terdahulu sudah dikemukakan dua repertoar tradisi dendang Sikambang dalam pertunjukan rabab pasisia yaitu lagu Sikambang Tinggi dan lagu Sikambang Data. Kedua repertoar musik kaba tersebut menempati posisi melodis yang berbeda dalam menggunakan nada-nada yang tersedia dalam register tangga nadanya, introduksi (intro) atau pembukaan lagu kaba Gadih Basanai memposisikan nada-nada tertinggi dari tangga nada. Melodi yang dibawakan oleh instrumen rabab bergerak menurun dari nada D5 sampai ke nada B4.

Intro sebagai sajian pembukaan pertunjukan rabab pasisia menggunakan form (bentuk) melodi pokok yang sama, hal itu dapat dimainkan secara berulang-ulang

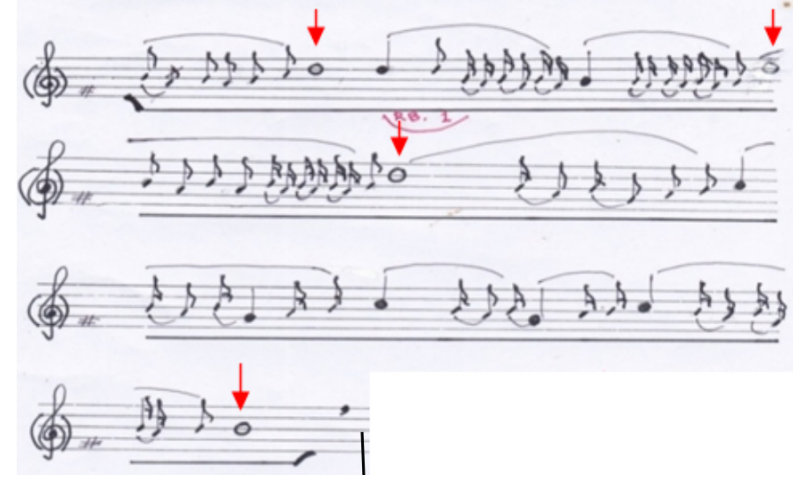

Gambar 3. Notasi Introduksi Kaba Gadih Basanai

Sumber: Hanefi

yang dikembangkan oleh musisi dengan menambahkan ornamentasi dan variasivariasi melodis. Kerja analisis dalam tulisan ini menampilkan satu bentuk melodi introduksi saja. Seperti pada gambar 3.

Gerak melodi intro lagu kaba Gadih Basanai di atas dapat dilihat bagaimana tukang rabab menempatkan nada-nada tertentu yang berproses bergerak turun ke nada B4, nada-nada berdurasi panjang hadir seperti bertangga turun. Mulai nada D5 menuju nada D5, lalu turun ke nada berdurasi pendek dari itu nada C4, seterusnya turun ke nada B4 sebagai nada akhir bagian melodi intro. Kemudian berlanjut ke melodi dendang kaba Gadih Basanai yang bermula pada nada B4 menyambut nada akhir melodi intro.

Masih bergerak di wilayah nada-nada sumber yaitu repertoar Sikambang Tinggi, bagian lagu Pasambahan (persembahan). Contoh melodi pada notasi di atas tiga frase melodi dendang (nyanyian) bergerak di sekitar nada B4, melodi tersebut menggunakan sumber nada-nada pada lagu Sikambang Tinggi. Pergerakan nada-nada pokok bergerak pada nada-nada A4-B4-C4, dan wilayah pergerakan nada-nada pada melodi seterusnya dengan 


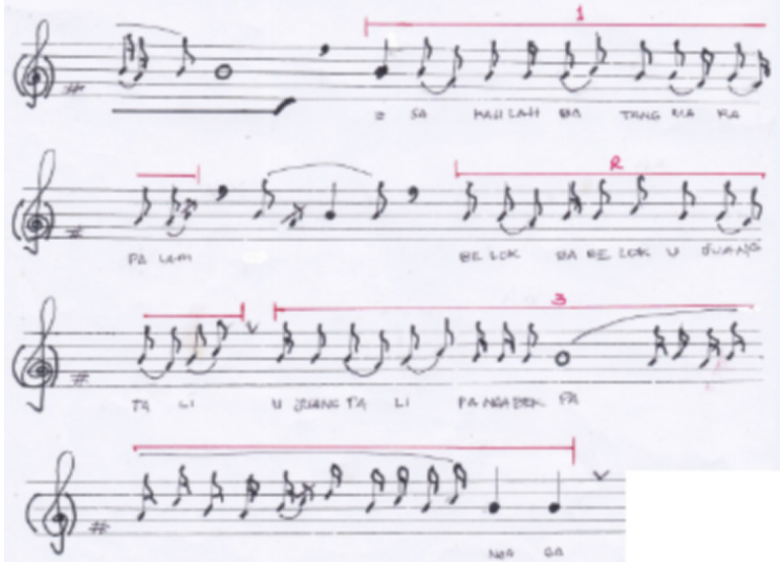

Gambar 4. Melodi vokal Pasambahan bersumber dari lagu Sikambang Tinggi

Sumber: Hanefi

menggunakan sumber Sikambang Tinggi dapat dilihat pada lampiran. Pada frase-frase tertentu nada A4 menjadi penting, pergerakan melodi pada frase tersebut didominasi nada A4, misalnya yang terjadi pada frase 7 , jelas sekali melodi rabab (RB2) mengantar (antaran) ke nada A4 sebagai nada awal melodi pada frase tersebut, kemudian kembali ke dominasi nada B4.

Setelah melodi introduksi, tukang rabab menyanyikan teks pasambahan, sumber gerak melodi tetap pada materi nada Sikambang Tinggi, walaupun ada gerak melodi menyinggung nada-nada pada wilayah Sikambang Data tetapi itu hanya hiasan saja. Dari segi penggunaan nada-nada yang bersumber dari lagu Sikambang Tinggi maka ekspresi melodis masih dalam 'ruang ekspresi' yang sama dengan melodi intro lagu kaba Gadih Basanai, tetapi ada sedikit perkembangan mendasar dari tingkat nada gerak melodi yaitu: pada intro gerak nada-nada menuju ke nada tertinggi dari register tangga nada sedangkan melodi vokal Pasambahan bergerak dari pusat nada yaitu nada B4 dan cendrung bertahan di situ di hampir di setiap nada akhir
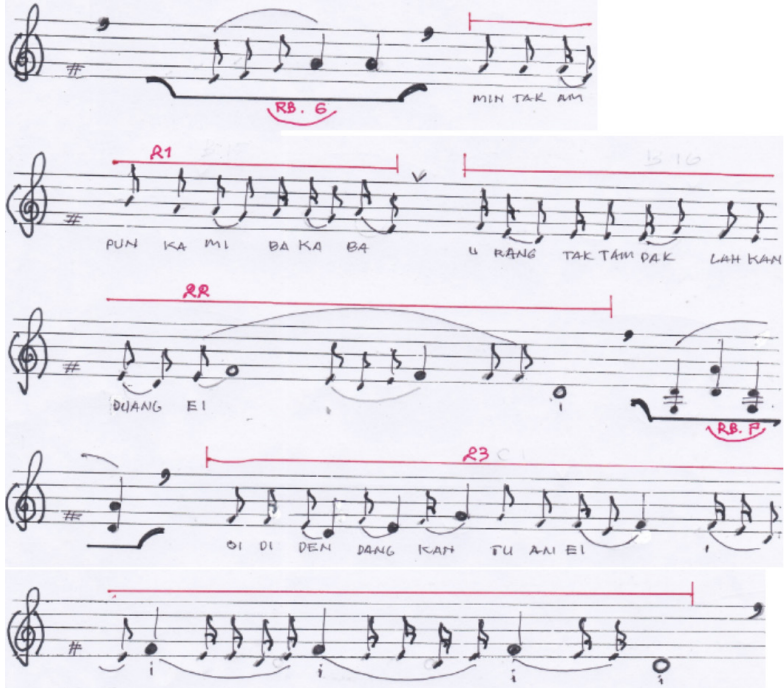

Gambar 5. Perubahan melodi bersumber dari Sikambang Tinggi Ke Sikambang Data Sumber: Hanefi

frase melodisnya. Menurut seniman rabab pasisia Idris Kambang bahwa teks Pasambahan selalu menggunakan materi nada-nada lagu Sikambang Tinggi, kesan melodi yang disampaikan (diekspresikan) lebih cocok dengan lagu ini (Idris 11-03-2018 wawancara).

Notasi di atas juga memperlihatkan akhir frase melodi intro lagu yang mengantarkan nada awal melodi Pasambahan dimulai pula dari nada yang sama yaitu nada B4 lalu berlanjut pergerakannya secara linear dari frase melodi 1 sampai ke frase 6. Masing-masing frase melodis ditandai dengan nada akhir setiap frase pada nada B4, maka cukup jelas peran introduksi lagu (RB 1) yang mengantarkan melodi vokal ke nada B4. Gejala ini telah memberikan gambaran awal bahwa melodi rabab tanpa dendang mempengaruhi bentuk frase melodi vokal yang akan dibawakan.

Gerak melodi vokal yang penting untuk mengungkap ekspresi cerita setelah kehadiran Pasambahan, selanjutnya dilihat bagaimana proses perubahan terjadi. Gambar 5 menggambarkan perubahan notasi. 
Mengakhir bagian Pasambahan, tukang rabab menampilkan gerak melodi menuju ke nada terendah melalui suatu proses yaitu didahului oleh antaran melodi rabab RB6 yang bermula dari nada E4 menuju A4, lalu disambut oleh melodi vokal (frase 21) bermula dari nada A4 menurun (discending) dari nada A4 menuju nada $\mathbf{E}$ dengan melisma sliding tone (nada luncur). Frase berikutnya menyambut dengan gerakan melodi menuju nada berdurasi panjang Fis4 (frase 22) lalu berakhir pada nada berdurasi panjang D4. Seiring dengan itu berakhirlah bagian melodi Pasambahan, kemudian melodi rabab megantarkan masuknya cerita kaba Gadih Basanai. Melodi rabab RB7 berupa melodi dua nada secara vertikal bergerak dengan teknik loss snare (menurut laras snare), yang menjembatani ketegasan akhir dari bagian melodi Pasambahan (frase 23).

Kaba Gadih Basanai dimulai dengan antaran melodi rabab (RB8) dengan gerak melodi yang dimulai darinada $\mathrm{A} 4$ menuju nada D5 yang secara melismatis mengakhirinya kembali ke nada A4 dalam bentuk nada appogiatura (nada sentak), kemudian disambut melodi vokal (frase 24) dimulai dari nada Fis4 menuju nada C5, artinya sudah ada tandatanda bahwa melodi selanjutnya akan dibawa ke ciri permulaan lagu Simarantang Tinggi yang bergerak pada wilayah nada-nada tinggi pada register tangga nada.

Pola melodi rabab yang mengangkat melodi (menaik) hingga nada D5 berdurasi panjang kemudian melodi vokal mengikuti nada awal Fis4 bergerak sampai menyentuh nada C5, lalu dilanjutkan oleh antaran RB9
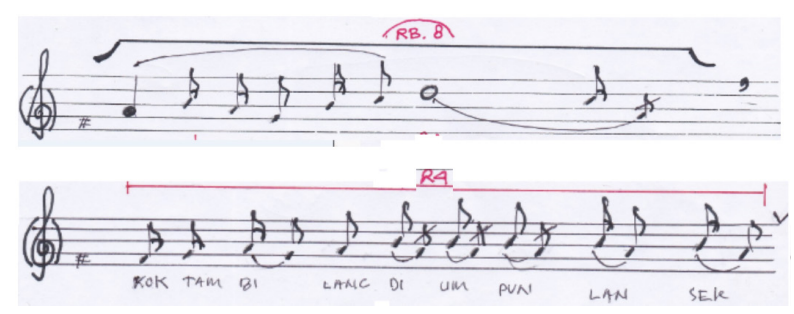

Gambar 6. Antaran melodi rabab menuju melodi vokal memasuki kaba Gadih Basanai Sumber: Hanefi

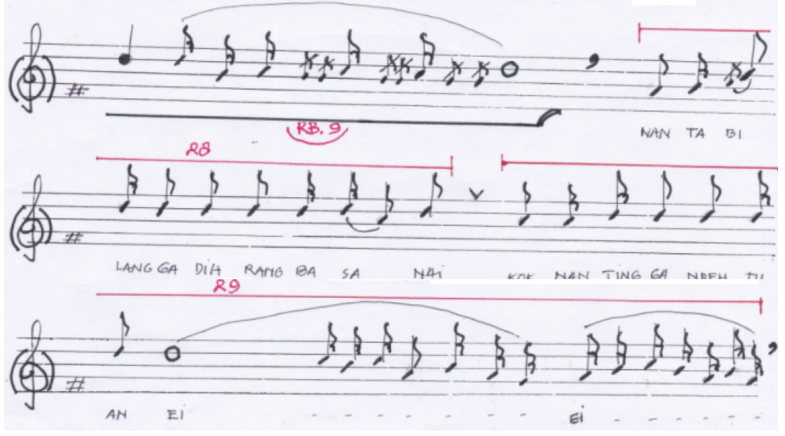

Gambar 7. Ciri karakteristik Simarantang Tinggi Sumber: Hanefi

yang mempertegas karakter Simarantang Tinggi yang diikuti oleh melodi vokal agar bergerak pada nada-nada tinggi tersebut. Lihat contoh notasi di bawah ini.

Bangunan suasana RB9 dan diberi bobot oleh melodi vokal dengan frase-frase kalimat teksnya berisi memperkenalkan seorang gadis (tokoh utama) Gadih Basanai di kampung Langang Sunyi. Tarikan melodi vokal oleh tukang kaba sangat ekspresif dengan suara tingginya mengesankan suatu misteri kehidupan seorang gadis akan diungkapkan. Gejala seperti ini merupakan tradisi musik kaba di wilyah budaya Pesisir Selatan (Darmansyah, wawancara tgl. 4 Juni 2018, di Painan).

Setalah memperkenalkan Gadih Basanai menggunakan Sikambang Tinggi lalu tukang rabab membawa cerita tentang keadaan Gadih Basanai. Pada tahap inilah perubahan sumber melodi vokal berubah ke sumber melodi Sikambang Data yang ditandai oleh 


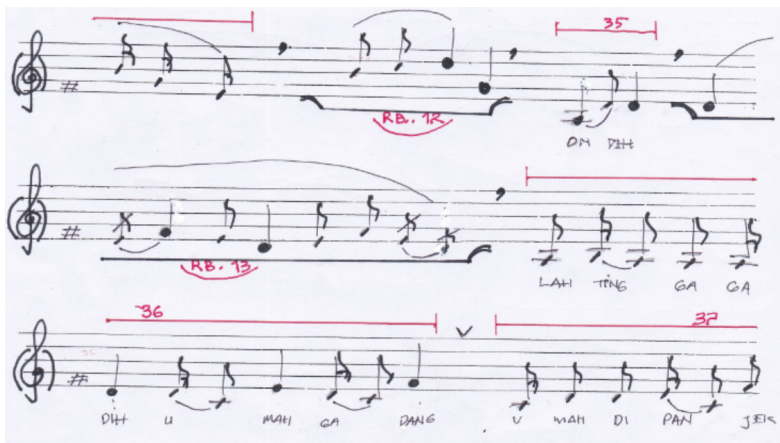

Gambar 8. Antaran melodi rabab ke Sikambang Data

Sumber: Hanefi

antaran-antaran RB12 dan RB13. seperti yang digambarkan pada gambar 8 .

Pada contoh notasi di atas ujung frase 34 meluncur turun ke nada E4, lalu disambut RB12 bergerak turun dari nada B4 ke G4. Kemudian melodi vokal meneruskan dengan silabel teks tambahan berupa keluhan ondeh ("duhai") dari nada oktaf rendah A3 bergerak ke nada D4. Kemudian ditegaskan oleh RB13 bahwa sumber melodis Sikambang Data. Frase 36 dan 37 memulai dari nada terendah A3 bergerak menuju nada akhir frase 36 nada Fis4 berdurasi agak panjang. "Perbedaan birama, aksentuasi frase melodi, interloking dan sebagainya memberikan rasa dan karakter yang khas. (Susandrajaya, 2018, hlm. 471)" Gerak melodi dalam karakter seperti ini dapat dilihat pada lampiran.

Gerak melodi bersumber pada Sikambang Data rupanya selalu didominasi oleh nada-nada Fis4, kehadiran nada tersebut berdurasi agak panjang melalui gerak-gerak melodi melismatis yang cendrung berada di bawah nada-nada Fis4 tersebut. Lihat gambar nnomor 9 .

Contoh notasi di atas memperlihatkan dominasi nada Fis4 baik pada melodi vokal

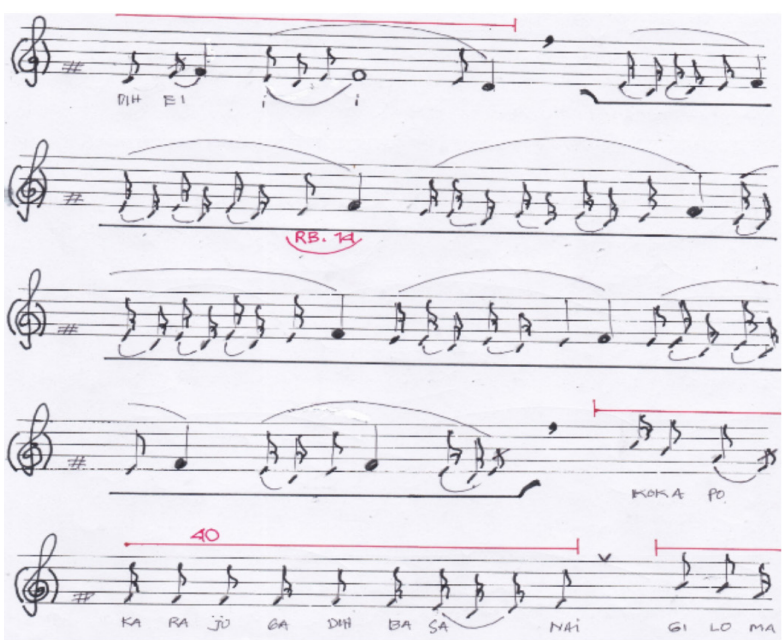

Gambar 9. Dominasi nada Fis4 Sumber: Hanefi
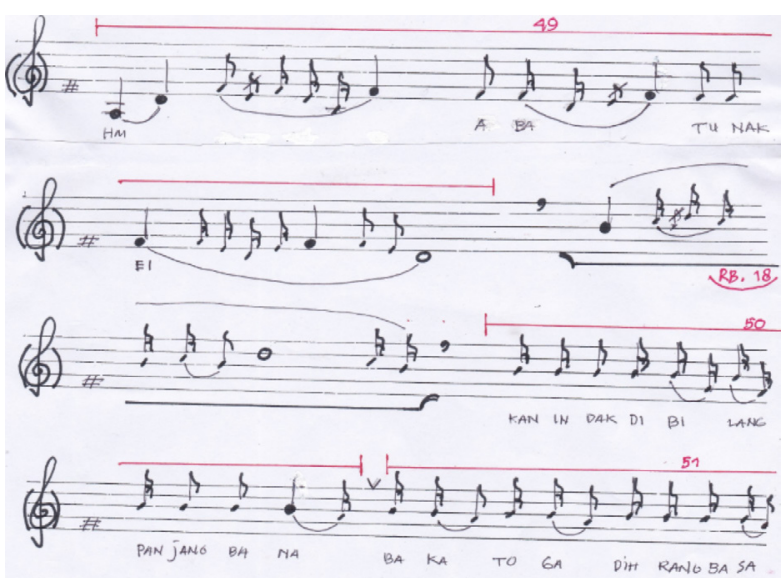

Gambar 10. Perubahan sumber melodi ke Sikambang Tinggi Sumber: Hanefi

frase 39 diterus oleh melodi rabab RB14, lalu frase melodi vokal selanjutnya yang berisi teks kaba tentang kesengsaraan seorang Gadih Basanai. Hal yang sama berlanjut dapat dilihat pada lampiran. Gejala melodis bersumber dari Sikambang Data berakhir pada frase 49 melodi vokal, dan ditegaskan oleh RB18, lalu disambut melodi vokal frase 50 dimulai dari nada B4. seperti pada gambar nomor 10 .

Cukup jelas perubahan sumber melodi ke Sikambang Tinggi, frase 49 masih memprlihatkan orientasi gerak melodinya ke nada Fis4 tetapi berakhir pada nada D4, 
tetapi antaran oleh RB18 memulai melodinya di nada B4 dan berakhir pada nada D5 berdurasi panjang menurun ke nada B4. Kemudian disambut oleh melodi vokal frase 50 memulainya pada nada B4 (nada penting pada Sikambang Tinggi), selanjutnya melodi bergerak pada sumber Sikambang Tinggi yang artinya suasana dan karakter melodis berubah, tentu diiringi pula dengan perubahan karakter cerita kaba yang dituturkan.

Isi teks melalui frase-frase melodis berisi tuturan Gadih Basanai dan kesengsaraan yang dialaminya. Suasana sedih lebih mengemuka didukung oleh karakter melodi vokal dan diperdalam oleh antaran-antaran melodi rabab (RB). Melodi vokal yang yang dituturkan mengandung sentuhan seni musik (melodis) sudah cukup mempengaruhi perasaan orang yang mendengarnya, kemudian datang pula sentuhan melodi rabab meneruskan imajinasi lebih ke dalam perasaan, dan melodi itu tanpa teks dan terbuka sekali menafsirkannya.

Setelah berjalan melalui sejumlah frase melodis, suasana berubah lagi ditandai gerak melodi mengarah ke sumber Sikambang Data karena itu otomatis isi cerita berubah pula. Hingga frase 64 kesengsaraan itu diungkap oleh tukang rabab, lalu pada frase melodi vokal ini gerak melodi mengarah ke Sikambang Data, RB26 juga merespons dan memberi tanda-tanda ke arah yang sama dan tanda itu prinsipnya sama dengan tanda $R B$ sebelumnya pada pergantian sumber melodi dari Sikambang Tinggi menuju Sikambang Data. Lihat contoh pada gambar nomor 11.

Pada gambar 11 notasi dimulai ujung melodi vokal frase 70 langsung disambut RB28

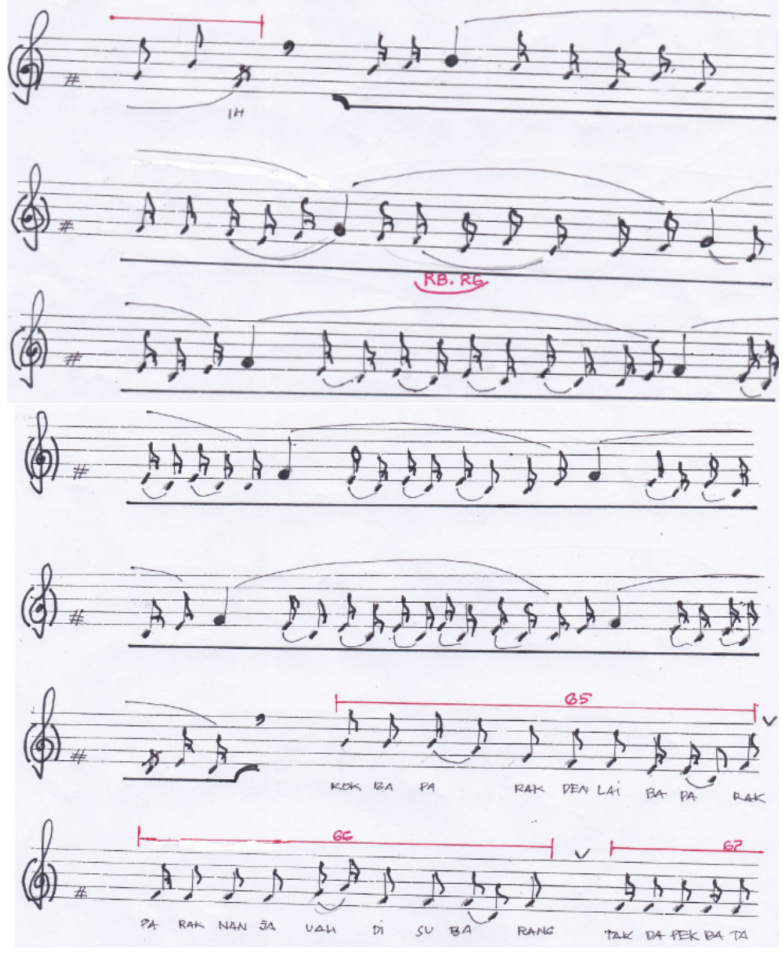

Gambar 11. Melodi rabab (RB26) mengantar ke melodi bersumber Sikambang Data

Sumber: Hanefi

yang mengantar ke sumber pergerakan melodi Sikambang Data yang kemudian menempatkan nada Fis4 orientasi pergerakan melodi vokal. Sebagaimana sudah disinggung sebelumnya bahwa melodi vokal cendrung mengarah ke bentuk parlando rubato, peran melodi rabab mengiringi melodi vokal hampir tidak terasa dan melodi vokal cendrung berjalan sendiri sehingga tukang rabab terfokus menuturkan alur cerita.

Isi cerita kaba yang dituturkan tukang kaba pada bagian ini mengungkapkan keluhan-keluhan Gadih Basanai ingin keluar dari kesengsaraan itu, tiba-tiba diketahui oleh dua orang pengembara (disebut dagang mularat) yang lewat di depan rumah Gadih Basanai. Akhir bagian yang singkat ini kemudian berubah lagi kembali ke melodi bersumber dari Sikambang Tinggi ditandai oleh RB30, melodi antaran rabab ini mengunakan 


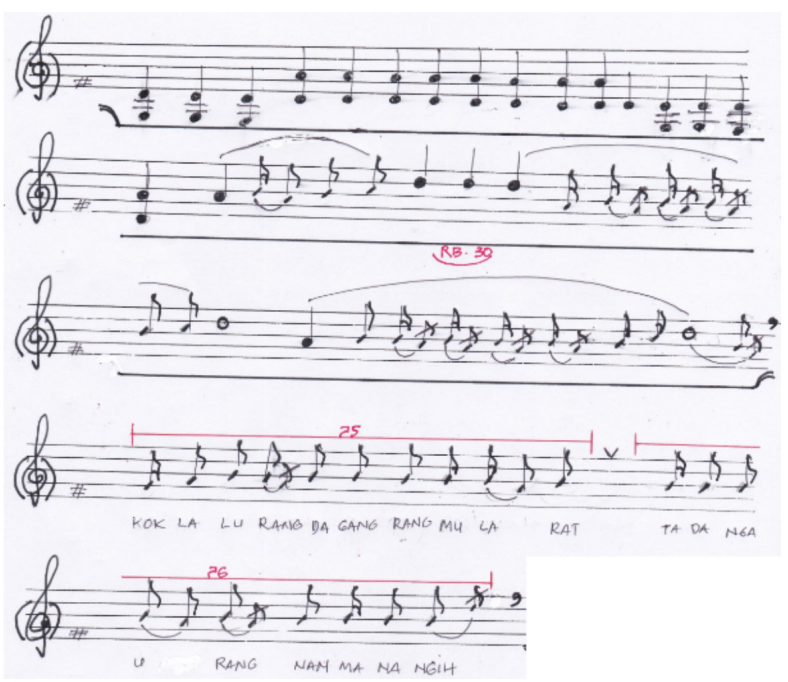

Gambar 12. Gerak melodi rabab (RB30) dengan dua nada vertikal Sumber: Hanefi

pergerakan melodi dua nada vertikal dengan teknik loss snare. Seperti teknik melodi serupa sebelumnya (RB7) yang menjembatani melodi vokal ke nada terendah, RB30 menjembatani (antaran) melodi vokal menggunakan sumber Sikambang Randah bergerak ke melodi vokal bersumber dari Sikambang Tinggi, seperti yang dituangkan padagambar nomor 12 .

Gerak melodi vokal yang kembali menaik ke Sikambang Tinggi menandakan isi cerita lebih sedih dari sebelumnya, yaitu yang cerita dituturkan dengan pergerakan nada-nada Sikambang Data. Dapat dilihat pada teks kaba bahwa yang disampaikan tukang rabab Gadih Basanai sangat sedih dengan penderitaannya dan selalu menagisinya. Suasana yang diungkap secara musikal oleh pergerakan melodi Sikambang Tinggi bergerak dengan sejumlah melodi rabab (RB) memberi tekanan kedalaman kesedihan hingga frase 94 .

Perjalanan Gadih Basanai dalam kaba menunjukkan seuatu perjuangan hidup seorang wanita Minangkabau yang ditinggal mati kedua orang tua serta sanak saudaranya.
Berbagai peristiwa sepanjang perjalanannya merupakan simbolisme dari perjalanan hidupnya. Gejala cerita kaba Gadih Basanai juga ditemui dalam cerita Wong Menak. Sebagaimana yang diungkapkan oleh Muh. Syahrul Qodri bahwa menurut dalam cerita Serat Menak ini dikisahkan melewati berbagai macam perjalanan, melewati hutan belantara, lautan samudra, gunung, lembah, dsb. Akan tetapi perjalanan itu merupakan simbolisme dari perjalanan hidup tokoh tersebut, betapa beratnya menjalani kehidupan dengan berbagai rintangan dan cobaan, dan tokoh Wong Menak mampu melewati itu semua sehingga layak dijuluki sebagai Jayeng Jurit (konsep kesempurnaan tokoh Wong Menak dalam Wayang Sasak). Gejala yang sudah diuraikan beserta contoh-contoh pergerakan melodi vokal dan peran melodi rabab menjadi dasar untuk memahami suasana peristiwa yang di-kaba-kan (ceritakan) sehingga penyusun naskah lebih mempertimbangkan ekspresi tradisi musikal mengungkap kaba menjadi kekuatan mengadaptasi Kaba Gadih Basanai menuju Film Gadih Basanai. Demikian, uraian yang tersaji dapat mewakili secara keseluruhan dari fakta seni pertunjukan musik rabab pasisia yang berjudul kaba Gadih Basanai.

\section{PENUTUP}

Tradisi Bakaba Dalam Rabab: Sebuah Adaptasi Menjadi Film, merupakan sebuah penawaran untuk mengangkat seni tradisi yang sudah terdesak oleh kemajuan teknologi. Bakaba hampir setiap daerah di Minangkabau memilikinya, namun bakaba yang memakai 
alat musik pengiring rabab atau dikenal juga dengan istilah babiola hanya dimiliki oleh masyarakat Pesisir Selatan. Biasanya penuturan kaba ini membawakan cerita yang kadang kala disesuaikan dengan permintaan panitia atau yang punya hajat, dengan arti kata tidak tertutup kemungkinan tukang kaba membawakan cerita sendiri. Bagus tidaknya sebuah cerita tergantung penuturan tukang kaba. Sering tukang kaba yang bijak biasanya akan menarik penonton dengan berbagai atraksi, baik dalam bertutur maupun kelincahan memainkan melodi rabab sebagai musik pengiring atau pembangkitkan suasana.

Aksestuasi yang dilahirkan melalui vokal yang didukung penuh oleh gesekan rabab melahirkan melodi yang indah. Secara musikal pergerakan melodi rabab diutamakan untuk mengisi introduction lagu, interlude, dan antaran atau jembatan dari satu suasana ke suasana lain, memperdalam rasa kesedihan yang disampaikan melalui teks atau syair; melodi dendang adalah melodi dari tuturan tukang rabab menyampaikan cerita. Ada bagian-bagian tuturan melodi dendang diringi oleh rabab dan ada pula bagian-bagian yang tidak diiringi melodi rabab (biasanya pada melodi yang bersumber dari Sikambang Data).

Sumber dua lagu masing-masing lagu Sikambang Tinggi dan lagu Sikambang Data terkait dengan ekspresi musikal cerita yang dibawakan, kehadiran sumber melodi dari lagu Sikambang Tinggi biasanya mengawali lagu dan mengawali bagian-bagian cerita serta mengisi tensional musik pada bagianbagian tertentu. Sedangkan lagu Sikambang Data digunakan untuk bagian cerita yang mengutamakan peristiwa dalam kapasitas yang panjang.

Secara umum, penggunaan nadanada lagu Sikambang Tinggi dalam musik tradisional rabab pasisia kaba Gadih Basanai mengungkapkan suasana-suasana kehadiran atau memperkenalkan tokoh, menggambarkan lingkungan tempat kejadian, peristiwaperistiwa sedih dan atau memperdalam perasaan sedih. Penggunaan lagu Sikambang Data digunakan sebagai penjelas peristiwa, perjalannya bagian cerita, dan monolog.

\section{Daftar Pustaka}

Ardianto, D. 2014 Dari Novel Ke Film: Kajian Teori Adaptasi Sebagai Pendekatan dalam Penciptaan Film

Bruno Nettl. 1964. Theory and Method in Ethnomusicology : Chapter 5: "Description of Musical Compositions. Pnj: Marc Perlman. London: The Free Press GCML

Djelantik. A. M. 2008. Estetika: Sebuah Pengantar. Jakarta: MSPI

Elina, M. (2018) Pengemasan Seni Pertunjukan Tradisional Sebagai Daya Tarik Wisata Di Istana Basa Pagaruyung. Panggung, 28 (3), 304-316

Nettl, Bruno. Theory and Method in Ethnomusicology. New York : The Free Press a Devision of Macnillon Publishing. INC. 1964.

Puspitasari, D. 2016 “Narasi Cahaya Kearifan Lokal dalam Film Sang Pencerah: Karya Hanung Bramantyo". Panggung 26 (4)

Susandrajaya, 2018, Inovasi Talempong Gandang Lasuang Dalam Upaya Pelestrian Seni Tradisi. Panggung, 28 (4), 464-481.

Taslim, Andi. 2019. Peristiwa Teater Tumbuh Sebagai Konstruksi Politik Tubuh, Panggung , 29 (2), 102-115. 